therapeutical experiments which are manifest on the outside of the body. Yet surgery fell under the proscription of a handicraft, and as such was eliminated from the colleges of physicians both in London and Paris. Thus the genuine work of such men as Paré and Gale were without influence upon medicine, and thus it came about that Francis Bacon said of the physicians of Harvey's day that they saw things from afar off, as if from a high tower. From Erasistratus to Celsus, physicians practised medicine as one art. Galen taught, not the simplicity, but the unity of medicine ; and Littré points out that this unity is consistent in the Hippocratic writings. Surgery, by virtue of its imperative methods, was kept clear of philosophy on the one hand and of humanism on the other. Fortunately for Harvey, his master, Fabricius, was as great a surgeon as anatomist ; and such was Fallopius. Thus it was that medicine, at the end of the Middle Ages, had not recovered the standard of Alexandria. And against this adversity, also, had the founder of physiology to contend.

Happily the Arabian scholastic philosophy took its root in Alexandria when neo-platonism had veered towards Aristotle, and it was therefore more uniformly peripatetic than the Christian scholasticism. It is one of the signs of the greatness of Aristotle that, thus garbled and glossed, his power made itself felt in the thirteenth century, chiefly by the great Franciscans Alexander Hales, Roger Bacon, and William Ockham-Roger Bacon, whom we may call the first of the natural philosopher of the West. This former renascence determined the second period of the Middle Ages : the period distinguished by the Arabian version of Aristotle, by a check to the chimæras of realism, by some liberty of secular knowledge-for even bishops came out of the school of Toledo-and again by the coming of the Friars, whose influence upon the thought of the Middle Ages was a curious proof that, as all ways are said to lead to Rome, so all systems of thought, in spite of the thinkers, led to natural science. The logic and rhetoric of the Dominicans, by their rationalism, defined, and in defining restricted, the dominion of the Faith. Men got used to reason, and made a language for thought. And in the history of the unlearned Friars Minors we find, as elsewhere in history, that mysticism is more favourable to natural knowledge than the passionate dogmatism of Clairvaux or the dogmatic rationalism of St. Thomas. The Victorians, as Gerson after them, despised reason rather than feared it ; mysticism makes for individual religion, as in Glisson and Newton, rather than for the Church. Hence it may have been that independent thinkers, like Hales and Bacon and Ockham, entered the Franciscan Order. The former renascence bred also a more tolerant spirit. Albert of Cologne owed as much to Avicenna as St. Thomas to Averroes : sages technically damnable, yet "mighty spirits," worthy of reverence. Dante put in hell, but on green meadows, in an open place, lofty and luminous, not only Aristotle, Plato and Socrates, but also Euclid, Ptolemy, Hippocrates, Avicenna, Galen and "Averroes who made the great commentary." Universities were founded in France, England and Italy. But the natural science which made the second re. nascence irresistible was absent from the former; and at the end of the century a reaction set in. During the two following centuries in Spain freedom of thought was crushed out by the Church ; but in the conflagration of books of philosophy, medical works, such as the "Colliget" and the Commentary on Galen of Averroes, were largely spared; yet in the fourteenth and fifteenth centuries the very name of Averroes, "the mad dog that barked against the Christ," not only became ecclesiastically accursed, but also began to signify loose life as well as free thought; a resentment of which there was no trace in Albert or Aquinas.

Averroism, however, held its ground at Padua, which had become celebrated for medicine as Bologna for law; and although Averroism, like any other philosophy taught as a separate study, decayed, yet, effeteias it was, it kept the ground open at a time when the tide was turning against free thought when the commercial supremacy of Venice was declining, when the Spanish Inquisition was established in Rome, and when even the influence of the Florentine humanists was rather agains natural knowledge than for it. No doubt the coarse and disingenuous scepticism of the physicians of North Italy and their pretentious manners alienated the humanists, not only from themselves, but also from natural philosophers such as Telesius and Galileo ; and Averroists and humanists alike stood by at the burning of Bruno. Harvey entered Padua at a fortunate time he found Galileo engaged in teaching, and also in methodical research; and Galileo was not only a great discoverer, but was the first to formulate fully and clearly that method which we know under the name of the inductive method. The discovery of Greek texts had destroyed the conventional Aristotle and the conventional Galen; Gregory, by the reform of the calendar, had put the axe to the root of astrology; Newton was soon to carry terrestrial physics into celestial spheres; and Boyle was soon to create chemistry; while anatomy was fully awake already. In England, moreover, with the accession of Elizabeth more spacious times were assured, and Charles protected Harvey. Clinical teaching had been established at Padua by Fracastorius and Montanus, to be pursued in Heidelberg, Leyden and Vienna. Physiology, however, awaited Harvey. Servetus had buried his conception of the lesser circulation under a pile of theology; Columbo and Fabricius had prepared the way, not so much by the value of their discoveries as by their practice of the experimental method in this science; for the anatomists, Galenists to a man, had done next to nothing for physiology.

The genius and courage required to make discoveries like that of the circulation of the blood cannot be measured directly; there is no method of determining the specific gravity of such adventures; I have tried, however, to shadow forth the weight of the social systems, opinions, prejudices and habits against which Harvey's gigantic effort was made. Almost in the year of the pullication of the "De Motu Cordis" (A.D. 1628), the Parliament of Paris issued an edict that no teacher shall promul. gate anything contrary to the accepted doctrines of the ancients. Under such conventions Harvey's discovery burst like an earthquake ; under corrupt Galenism, venerable sophistries, current abstractions bequeathed by realism, and long-winded dialectics on critical days, coctions, derivatives or revulsives, and dogmas based on uncritical subservience to texts. His work stood out even more ascendant against a lurid background of folk superstitions - of vampyres, witch-burning, magic, cabbalism, astrology, alchemy, chiromancy and water-casting. In terrestrial and celestial physics, Galileo, persecuted as he was, had some strong current with him; Copernicus was before him, Kepler was beside him : but in physiology upon the path of Galen the waters had closed as upon the track of a great ship, and among Harvey's contemforaries and immediate forerunners there was none to claim a share with him in the discovery of the central fact of physiology, or in his application of the method which opened the way to Pecquet, Gilisson, Steno, Wharton, Willis, Haller and Bernard.

\section{THE ANNUAL CONGRESS OF THE GERMAN ANTHROPOLOGICAL SOCIETY.}

THE thirty-first Congress of the German Anthropological Society was held in the University town of Halle from September $24-27$. In addition to its rich University collec tions, a special interest is attached to Halle as being the seat of the oldest German society for encouraging the study of natural science, viz. the Leopoldina-Carolina Academy, which is thus comparable to the Royal Society in this country. To students of prehistoric archæology, the Prussian province of Saxony is chiefly interesting from the fact of the existence of copper-mines at Eisleben, some little distance from Halle. The meetings were held under the presidency of Prof. Virchow, assisted by Prof. Ranke. At the opening session on Monday, September 24, the presidential address (dealing with the general progress of anthropological study and teaching) was followed by a series of addresses from representatives of the University and town of Halle, of which that of the local secretary, Dr. Förtsch, is particularly noteworthy as containing a sketch of local prehistoric archæology, a field of research in which Dr. Förtsch has been particularly active, and which he has popularised with evident success. Of the subsequent communications to the Congress, the majority of which dealt with archæology, there appear to us most worthy of mention the discussion opened by Prof. Virchow on the "Earliest appearance of the Slavs in Germany," and the account (illustrated with excellent lantern slides) given by Dr. Birkner (Munich) of the investigation of the graves of the German Emperors in Speyer. Prof v. Fritzsch (Halle) and Dr. Lehmann-Nitzsche (La Plata) ren. dered interesting accounts of discoveries of prehistoric man in Thiiringia and in the Argentine respectively, the latter record

No. 1617 , VOL. 62] 
being still the subject of investigation as regards the exact antiquity (Tertiary period) claimed for the find.

It is a matter of some surprise that the department of Physical Anthropology should not have been the subject of more papers than were actually presented at Halle, which University claims the two Meckels and Welcker among its former professors of anatomy. The chief contributions to this subject were those of Dr. Schmidt-Monnard (Halle) on the relation between the growth and the weight of children of both sexes ; of Dr. Eisler (Halle) on the Musculus sternalis; and of Prcf. Klaatsch (Heidelberg) on the method of research adopted by anatomists, illustrated specifically by observations on the "short head" of the Biceps femoris muscle in the mammalian series.

The chief excursion of the Congress was made on Wednesday, September 26 , to Eisleben, where the copper-mines already referred to were visited, and demonstrations of copper-smelting were given by representatives of the Mansfeld $\mathrm{C} o$. Subsequently the local collection of prehistoric pottery, \&c., was inspected.

The concluding session was held on September 27, when the presidency (for the ensuing year) was assumed by Prof. Waldeyer (Berlin). It is a matter of interest to note that the Congress was made the occasion of circulating "special inquiry" sheets regarding the structure and building of boats in all parts of Germany. General proposals regarding cartography and systematic records for provincial localities were brought forward by Dr. Voss (Berlin).

In addition to the anthropologists already mentioned in the foregoing notes, there were present Freiherr v. AndrianWerburg (Vienna), Prof. Hein (Vienna), Prof. Montelius (Stockholm), Prof. Koganei (Tokio), and others to the number of about one hundred and twenty.

\section{ANTHROPOLOGY AT THE BRITISH} ASSOCIA TION.

THE Section of Anthropology had a very successful session under the presidency of Prof. Rhys ; indeed, it was one of the very best meetings of Section $H$ in the history of the Association. Nearly every department of the subject was represented and that too by new and original contributions. It is interest ing to note the different lines which members of the Universities of Oxford and Cambridge are at present taking up. The field of Classical Archæology is offering rich prizes to Arthur Evans, Hogarth, and Myres; while the expeditions of Hose, Stanley Gardiner, Haddon, Skeat, and others are providing material for a more complete knowledge of primitive peoples.

\section{I.-Physical and Experimental Anthropology.}

\section{(1) Somatology.}

Dr. John Beddoe, in a short paper on the vagaries of the cephalic index, described two long.headed skulls which had the general characters of dolichocephaly, but the one that appeared the more typical had a latitudinal index (living) of 82.3 , owing to retarded ossification of the posterior part of the temporoparietal suture; but for this the author thought the index would not have exceeded 77. Prof. Macalister, as at the last meeting of the Association, deprecated the importance usually ascribed to the cephalic index.

Prof. A. Francis Dixon read a paper, entitled "On certain markings on the frontal part of the human cranium and their significance." An examination of the frontal region of the cranium shows that, in many cases, grooves or channels are present on the bone, corresponding to the branches of the supra-orbital nerves. Their presence indicates a want in proportion between the growth in length of the nerves and the amount of expansion of the underlying part of the cranium. The nerves night be looked upon as constricting cords which become depressed in the developing bone as the cranium expands. In races in whom the grooves are common, and strongly marked, we would expect the presence of a tendency towards increased development and capacity of the frontal part of the cranium; while, on the other hand, in races in whom the grooves do not occur, or are rare, and but feebly marked, we would expect to find much uniformity in the shape and size of the cranium, in. dicating that none of its various parts are tending towards an increased development. In this connection it is interesting to note that the frontal gronves are almost never found in Australian and Tasmanian skulls, that they are rare among Melinesians, NO. 1617 , VOL. 627 slightly more common anong Polynesians, while among Bush men and negroes, especially in Zulus and Kaffirs, they are very common, and often extraordinarily well marked.

Mr. W. L. H. Duckworth described nine crania collected by Mr. J. Stanley Gardiner in his expedition to Rotuma. As might have been expected from the position of the island, the skulls could be resolved into two types, one of the form of cranium usually found among Polynesian. peoples, though possessing something of a Mongolian aspect; the other was of distinctly Melanesian affinities. The paper was well illustrated with lantern slides.

A second paper by Mr. Duckworth was on some anthropological observations of the Pangan tribe of aborigines in the Malay Peninsula made by Mr. J. Laidlaw in the Skeat Expedition. Mr. Duckworth measured one adult male skeleton the stature of which was about five feet, which is the average height of the men measured by Mr. Laidlaw. The latter describes the people as having a skin colour of varying shades of dark brown, and the black hair is in some cases frizzly and in others more or less curly or wavy. Mr. Duckworth regarded the skull as of a negroid type with infantile characteristics. It is probable that the skeleton in question belonged to a half-breed Negrit to and Malayan individual.

The developmental changes in the human skeleton from the point of view of anthropology were described by Dr. David Waterson. A comparison was instituted between the bones of the embryo and those of the lower races of mankind and of the higher apes, both as regards their relative length and their characters. As it has been shown that the curvature of the spine in the lumbar region is a post-natal development, and one adapted to the assumption of the erect attitude by the infant, it can also be shown that in a similar way the configuration of the bones of the lower extremity alters after birth, before the infant can stand erect.

Prof. A. Macalister discoursed on perforate humeri from ancient Egyptian skeletons. In examining those from Libyan graves, he was struck with the large number of humeri which had a supra-articular perforation, the proportion of such among these old Egyptian remains being much greater than among other races. He found that these perforations reached 57 per cent. among the ancient Egyptians, whereas among average English people they ranged about 3 per cent., and ro per cent. among Neolithic skeletons, while the percentage rose to 53 in the skeletons of Indians from Arizona.

A paper on the sacral index was read for Prof. D. J. Cunningham. Inasmuch as the true length of the sacral por. tion of the vertebral column is not indicated by the shortest distance between the apex and base of the sacrum, but rather by the length of the curve formed by the sacral vertebræ, it is proposed that, in making measurements for the determination of a sacral index, "length" should be measured by using a tape along the concavity of the sacral curve, and not by calipers, one limb of which is placed upon the base and the other on the apex of the sacrum. Breadth (measured by calipers in the ordinary manner) multiplied by 100 and divided by length, measured in the manner indicated, gives the true sacral index. The curvature of the sacrum may be conveniently plotted by taking a tracing from a strip of soft metal which has been previously adapted by pressure to the front of the sacrum along its middle line. The index of curvature may be expressed by the number derived by multiplying the height of this plotted curve by Ioo and dividing by the number corresponding to the true length of the sacrum.

Dr. Cunningham communicated a second paper on the microcephalic brain, which also was read by Dr. Dixon, and illustrated with a large number of lantern slides. The brain of the microcephalic idiot may exhibit features which do not merely represent a "fixed" embryonic condition. In one specimen the arrangement of the fissures and sulci is found to approach more closely the ape than the human type, and in almost every furrow some simian character can be detected. These simian characters must not be considered mere foetal conditions rendered perma. nent. The ape-like condition existing in this brain does not as a whole correspond to that of any one ape, or group of apes, but there is a complicated mixture of features some of which are characteristic of high apes, while others find a parallel in the brain of low apes. The microcephalic brain may be regarded as a partial "atavism." So far as its surface markings are concerned, the specimen noted has reverted in part, or wholly, to an arrangement which, in all probability, existed in some early stem-form of man 